УДК 338.24:316.48

https://doi.org/10.52058/2708-7530-2022-1(19)-361-374

Пілько Андрій Дмитрович кандидат економічних наук, доцент, доцент кафедри економічної кібернетики, Прикарпатський національний університет імені Василя Стефаника, вул. Шевченка, 57, м. Івано-Франківськ, 76018, тел.: (050)373-52-87, https://orcid.org/0000-0002-4418-6877

\title{
ФОРМУВАННЯ МОДЕЛІ ОЦНЮВАННЯ ТА АНАЛІЗУ СОЦІАЛЬНОГО НАПРУЖЕННЯ ТА ЇЇ ЗАСТОСУВАННЯ В ДОСЛІДЖЕННЯХ СОЦІАЛЬНО-ЕКОНОМІЧНОГО РОЗВИТКУ РЕГІОНУ
}

Анотація. Актуальною задачею для дослідників $\epsilon$ ідентифікація на концептуальному та кількісному рівнях закономірностей процесів формування та розвитку соціальної напруженості, з'ясування причин та передбачення наслідків відхилень фактичних та прогнозних значень рівня соціальної напруженості від критичних, розробка та апробація прогнозних моделей розвитку соціальної напруженості заради профілактики та попередження можливих кризових ситуацій, пов'язаних з відхиленнями фактичних значень показників від прийнятного рівня.

В статті висвітленно окремі результати проведеного дослідження існуючих підходів до формування концептуальної моделі соціальної напруженості, а також розробка рекомендацій стосовно кількісного оцінювання та аналізу рівня соціального напруження в регіонах України.

Доведено, що в структурі концептуальної моделі соціальної напруженості на рівні регіону всередині окремо взятої держави необхідно враховувати основні чинники що впливають на соціальну напруженість на глобальному, загальнодержавному та регіональному рівнях.

На основі проведенного аналізу існуючих методик оцінювання та аналізу соціального нпруження доведено, що методики оцінювання рівня соціального напруження, засновані на застосуванні методів статистичного, економетричного, дискримінантного й ін. видів кількісного аналізу та обробці великих масивів статистичної інформації мають більшу практичну цінність 3 точки зору аналізу та прогнозування відповідних індикаторів та подальшої розробки проектів управлінських рішень щодо управління та регулювання розвитку процесів в суспільстві та економіці.

Для вирішення задачі кількісного оцінювання та аналізу рівня соціального напруження в регіонах України 3 урахуванням тенденцій соціального та економічного розвитку на загальнодержавному та міжнародному рівнях, в рамках проведених досліджень адаптовано 3 урахуванням наявної статистичної бази підхід до оцінювання та аналізу рівня економічної безпеки 
регіону. В рамках даного підходу пропонується застосування зваженої евклідової відстані для визначення фактичних та ретроспективних значень показника соціального напруження 3 подальшим розрахунком порогових рівнів соціального напруження та групування регіонів України за значеннями показників соціального напруження за кожен звітний період.

Ключові слова: соціальне напруження, трансформація, модель, евклідова відстань, оцінювання, аналіз.

Pilko Andriy Dmytrovych Candidate of Economic Sciences, Associate Professor, Associate Professor of the Department of Economic Cybernetics, Vasyl Stefanyk Precarpathian National University, Shevchenko St., 57, Ivano-Frankivsk, 76018, tel.: (050) 373-52-87, https://orcid.org/0000-0002-4418-6877

\section{FORMATION OF A MODEL OF ASSESSMENT AND ANALYSIS OF SOCIAL TENSION AND ITS APPLICATION IN SOCIO-ECONOMIC DEVELOPMENT RESEARCH}

Abstract. An urgent task for researchers is to identify at the conceptual and quantitative levels of patterns of formation and development of social tension, clarify the causes and predict the consequences of deviations of actual and predicted values of social tension from critical, development and testing of predictive models of social tension to prevent possible crisis situations related to deviations of the actual values of indicators from the acceptable level.

The article highlights some results of the study of existing approaches to the formation of a conceptual model of social tension, as well as the development of recommendations for quantitative assessment and analysis of the level of social tension in the regions of Ukraine.

It is proved that in the structure of the conceptual model of social tension at the regional level within a single state it is necessary to take into account the main factors influencing social tension at the global, national and regional levels.

Based on the analysis of existing methods of assessment and analysis of social tension, it is proved that methods of assessing the level of social tension, based on the use of statistical, econometric, discriminant and other quantitative methods and processing of large arrays of statistical information have much more practical value in terms of analysis and forecasting of relevant indicators and further development of draft management decisions to manage and regulate the development of processes in society and economy.

To solve the problem of quantitative assessment and analysis of social tensions in the regions of Ukraine taking into account trends in social and economic development at the national and international levels, the study adapted to the available statistical base approach to assessing and analyzing the level of economic security. This approach proposes the use of weighted Euclidean distance to determine the actual and retrospective values of social stress, followed by 
calculation of threshold levels of social tension and grouping of regions of Ukraine by values of social tension for each reporting period.

Keywords: social tension, transformation, model, Euclidean distance, estimation, analysis.

Постановка проблеми. Сучасний етап розвитку вітчизняної економіки, інститутів суспільства, а також системи соціальних відносин цілком закономірно характеризується вітчизняними та зарубіжними дослідниками як період системних трансформацій. Особливістю трансформацій, котрі спостерігаються вже протягом більше тридцяти років $є$ те, що вони торкнулися практично всіх без винятку сфер життя суспільства. Незважаючи на окремі позитивні аспекти таких перетворень, все більша кількість аналітиків відзначає посилення негативних тенденцій в соціальній сфері, котрі пов'язані 3 підвищенням рівня соціальної диференціації, i знаходять свій прояв в зростаючій поляризації соціальної структури суспільства, зростанні рівня бідності, зростанні корупції та соціального невдоволення наслідками трансформацій i реформ. Завдання органів державного управління та місцевого самоврядування полягає не в тому, щоб повністю усунути соціальну напруженість в суспільстві, а в тому, щоб не допустити іiі розвитку в некерований і руйнівний конфлікт через прогнозування виникнення ймовірних точок біфуркацій, після проходження яких розвиток соціальної та економічної систем є непрогнозований та некерований.

3 урахуванням процесів глобалізації, як справедливо зазначається в [1] дослідження соціальної напруженості в окремо взятому суспільстві $є$ просто безперспективним і таким що не відповідає вимогам динаміки розвитку глобальних та регіональних соціальних, економічних та геополітичних процесів. Іншими словами, досліджуючи питання соціальної, економічної безпеки, а також соціального напруження як передумови забезпечення та наслідку ефективності управління соціальною та економічною безпекою в окремо взятому регіоні чи окремо взятій країні, досліднику необхідно брати до уваги також відповідні процеси на загальнодержавному та міжнародному рівнях. Тут відразу слід зауважити, що даний аспект досить часто враховується дослідниками в процесі побудови концептуальних моделей соціальної напруженості. Натомість в математичних моделях, котрі використовуються для оцінювання та аналізу рівня соціальної напруженості на регіональному та національному рівнях даний аспект практично не враховується.

Актуальність дослідження вищеописаної проблематики визначається необхідністю наукового вивчення соціальної напруженості в сучасному українському суспільстві 3 розробкою науковообгрунтованих методичних підходів до іiі вимірювання, аналізу та прогнозування. Кінцева мета подібних міждисциплінарних досліджень - розробка систем моніторингу соціальної напруженості на регіональному та загальнонаціональному рівнях 3 наміром аналізу та прогнозування нарощування рівня соціальної напруженості i 
протестного потенціалу в окремих регіонах, котрі потенційно здатні призвести до скорочення темпів економічного розвитку, погіршення показників економічної та соціальної безпеки з урахуванням відповідних процесів на міжнародному рівні.

Аналіз останніх досліджень і публікацій. Слід відзначити, що на даний час вже сформовано певну систему поглядів на соціальну напруженість як на невід'ємний атрибут суспільного життя. В той же час погляди вчених на соціальну напруженість та підходи до іiі дослідження, аналізу і моделювання інколи можуть суттєво різнитися. Зокрема, в праці [1] увага акцентується на трьох парадигмах дослідження соціальної напруженості: функціоналістській, конфліктологічній та інтеракціоністській.

До найбільш відомих індикаторів рівня соціальної напруженості можна віднести індекс щастя, індекс соціального прогресу, індекс розвитку людського потенціалу, індекс якості життя, генеральний індекс соціального розвитку, регіональний стрес-індекс тощо [2].

Актуальною задачею для дослідників є ідентифікація на концептуальному та кількісному рівнях закономірностей процесів формування та розвитку соціальної напруженості, з'ясування причин та передбачення наслідків відхилень фактичних та прогнозних значень рівня соціальної напруженості від критичних, розробка та апробація прогнозних моделей розвитку соціальної напруженості заради профілактики та попередження можливих кризових ситуацій, пов'язаних 3 відхиленнями фактичних значень показників від прийнятного рівня.

Одні з перших успішних спроб кількісного вимірювання, оцінювання та моделювання рівня соціальної напруженості мали місце в Україні наприкінці 1980-х років. Термін «соціальна напруженість» досить вдало відображав стан тогочасних суспільних відносин і масової свідомості, і використовувався науковцями та політиками в якості синоніму несприятливої, гострої, кризової і навіть катастрофічної ситуації. Дослідження, спрямовані на розробку концептуальних та математичних моделей оцінювання, аналізу та прогнозування соціальної напруженості проводилися сектором проблем моделювання соціальних процесів Інституту соціології НАН України в ході виконання науково-дослідної теми сектора "Проблеми проектування процесів формування і задоволення соціальних потреб населення великого регіону на основі комп'ютерних моделей" [3]. Для вимірювання соціальної напруженості було запропоновано індекс, який розраховувався як зважена сума рівня задоволеності населення тими чи іншими благами.

В праці [4] запропоновано методику проведення розрахунку інтегрального показника напруженості соціально-економічного розвитку країни, яка грунтується на 8 етапному алгоритмі проведення кількісного аналізу показників соціального та економічного розвитку. Зважаючи на численні позитивні аспекти проведеного авторами даної статті аналізу, дискусійним залишається питання аналітичного забезпечення згортки 
індивідуальних показників в інтегральний показник напруженості соціальноекономічного розвитку. Заслуговують також на увагу спроби застосувати можливості економетричного моделювання для вирішення задач оцінювання та причинно-наслідкового аналізу між ключовими чинниками соціальної напруженості та самими показниками соціального напруження в розрізі регіонів України [5].

Крім того, питанням розробки комплексних методик оцінювання та аналізу рівня соціального напруження, котрі б враховували як результати кількісного аналізу наявної статистичної бази, так і результати соціологічних опитувань населення регіонів України 3 урахуванням процесів на загальнодержавному та міжнародному рівнях приділено недостатню увагу.

Мета статті. Метою статті $\epsilon$ висвітлення окремих результатів проведеного дослідження існуючих підходів до формування концептуальної моделі соціальної напруженості, а також розробка рекомендацій стосовно кількісного оцінювання та аналізу рівня соціального напруження в регіонах України з урахуванням тенденцій соціального та економічного розвитку на загальнодержавному та міжнародному рівнях.

Виклад основного матеріалу. Рівень соціальної напруженості $\epsilon$ ключовим параметром, який визначає той чи інший стан суспільства стабільний, відносно нестабільний та дуже нестабільний. Як справедливо зазначають в своїй праці науковці Інституту соціології НАН України [6, с.44 ], зміни цього параметру викликають не звичні поступові лінійні зміни, а саме фазові переходи, що притаманні складним, нелінійним системам і процесам. Як правило, такі переходи є спонтанними, надшвидкими та стрибкоподібними з непередбачуваними наслідками.

Як показують результати аналізу численних літературних джерел, дослідженнями питань соціальної напруженості на рівні держави та окремих іiі регіонів здебільшого займаються філософія, соціологія, економіка, політологія, конфліктологія, теорія державного управління та соціальна психологія.

Соціальна напруженість як явище знаходить свій прояв на соціальнопсихологічному i поведінковому рівнях i може мати одну або декілька наступних форм:

1) формування та поширення настроїв незадоволеності існуючою ситуацією в одній або декількох життєвоважливих сферах життя суспільства;

2) падіння рейтингів правлячої еліти, втрата довіри до інститутів влади та ключових інститутів суспільства;

3) посилення песимістичних настроїв в суспільстві, відчуття безвиході 3 ситуації що склалася та невпевненості в майбутньому;

4) формування ажіотажного попиту на товари основних продовольчих груп, а також на товари першої необхідності;

5) активізація міграційних процесів;

6) наростання протестних форм поведінки (мітинги, демонстрації, страйки, політичні голодування), що свідчать про загострення конфліктів; 
7) зростання обсягів тіньового обороту економіки;

8) зростання ролі неформальних інститутів узгодження та дотримання балансу інтересів на фоні повної або часткової недієвості формальних механізмів та інститутів;

9) активізація кримінальних угрупувань, екстремістських груп, котрі вдаються до організації різних форм саботажу та блокування роботи правоохоронних органів, органів державної влади, місцевого самоврядування, організації терактів та різних форм боротьби, в тому числі і збройної.

В працях [1,7] запропоновано підхід до формування теоретичних та методологічних засад побудови системної концептуальної моделі соціальної напруженості, базовими компонентами якої $\epsilon$ різнофакторні емпіричні підсистеми зовнішніх та внутрішніх чинників які характеризують:

1) соціальні контексти подій, які спричинюють наявний стан та зростання соціальної напруженості;

2) симптоми соціальної напруженості (емоційні, соціальні ментальні, поведінкові);

3) процеси взаємодій та комунікацій, які відображують об‘єктивний та суб‘єктивний адаптивний ресурс толерантного співіснування соціальних суб'єктів та їх протестний потенціал.

Ключовими елементами такої концептуальної моделі соціальної напруженості є не лише економічні, політичні та соціокультурні детермінанти можливого погіршення самопочуття населення та посилення соціальної напруженості, але й система індикаторів стану та функціональної ефективності соціальних зв'язків.

В праці [8] розроблено концептуальну модель соціальної напруженості, котра враховує процеси виникнення, розвитку та основні форми прояву соціальної напруженості. Визначальною особливістю даної моделі є те, що на концептуальному рівні встановлено відповідності між стадіями розвитку соціальної напруженості (якісною характеристикою), рівнями соціальної напруженості (кількісною характеристикою, отриманою за допомогою застосування кількісних методів аналізу) та формами прояву, які впливають на стабільність розвитку суспільства.

Як правило, дослідження соціальної напруженості на регіональному та національному рівнях є досить складною задачею, оскільки проблематично сформувати універсальну та чітку ієрархію чинників соціальної напруженості для будь-якого регіону чи держави. Зазвичай, в кожному окремо взятому регіоні чи державі буде своя унікальна ієрархія чинників, котрі 3 різною інтенсивністю та силою визначатимуть рівень соціальної напруженості.

3 урахуванням цього, в концептуальну модель соціальної напруженості на рівні регіону всередині окремо взятої держави слід включити основні чинники що впливають на соціальну напруженість на глобальному, загальнодержавному та регіональному рівнях.

Один 3 дослідників соціальної напруженості - Л.Едвардс, вказував на 
неможливість кількісного визначення рівня соціального незадоволення та тривожності, які $\epsilon$ передумовою до переходу до патологічного стану суспільства. [9]. Дане положення є дискусійним та суперечливим. Зокрема, В. Лапіна вважає, що універсальним показником соціальної напруженості виступає рівень протиріччя інтересів соціальних груп, що піддається виміру, але справжню цінність він буде мати тільки в сполученні 3 іншими емпіричними показниками [10].

Наявні на сьогоднішній день методики кількісного оцінювання рівня соціального напруження можна об'єднати в дві великі групи. Першу групу формують методики, засновані на використанні методів опитування респондентів. До другої групи відносять методики, в рамках яких передбачається обробка великих масивів статистичних даних за допомогою фактографічних методів аналізу.

Опитувальні методи вимірювання соціальної напруги в переважній своїй більшості реалізовуються через листи-анкети та тестові завдання. За допомогою опитування з'ясовується міра задоволення респондентів рівнем реалізації їх потреб. В кінцевому підсумку отримується деякий індекс, виходячи 3 максимальних та мінімальних значень якого можна зробити висновки про рівень задоволеності основних потреб респондентів та їхню суб'єктивну оцінку свого соціального самопочуття. Однак використання виключно опитувальних методів для оцінювання рівня соціального напруження не дозволяє відслідковувати причинно-наслідкові зв'язки між рівнем соціального напруження та ключовими чинниками, котрі його визначають. Крім того, за допомогою опитувальних методів вкрай важко об'єктивно спрогнозувати значення показника соціального напруження в майбутньому та відслідковувати його тренди. Зважаючи на беззаперечну значимість своєчасного отримання максимально об'єктивної інформації про ймовірне зростання рівня соціального напруження задля попередження соціальних конфліктів, масових заворушень та дестабілізації суспільства, виникає потреба в застосуванні фактографічних методів оцінювання та аналізу рівня соціального напруження.

Беззаперечним є той факт, що методики оцінювання рівня соціального напруження, засновані на застосуванні методів статистичного, економетричного, дискримінантного й ін. видів кількісного аналізу та обробці великих масивів статистичної інформації мають більшу практичну цінність 3 точки зору аналізу та прогнозування відповідних індикаторів та подальшої розробки проектів управлінських рішень щодо управління та регулювання розвитку процесів в суспільстві та економіці. Разом з тим, методики, засновані виключно на кількісних методах аналізу мають наступні слабкі сторони та недоліки, котрі досить повно розглянуті в праці [8, с.14]. Перш за все, сюди слід віднести наступне:

- дослідження, проведене на основі статистичних даних $\epsilon$ ретроспективним за своєю суттю i його результати не дають вичерпної 
інформації про рівень соціального напруження в суспільстві чи його окремих соціальних групах;

- спектр вибору показників для проведення оцінки рівня соціального напруження та його моделювання обмежується індикаторами, котрі подаються статистичною службою;

- за окремими значимими 3 точку зору цілей аналізу соціальної напруженості напрямами інформація може бути просто відсутньою або ж формуватись епізодично чи фрагментарно;

- недооцінка людського фактора як внутрішньої детермінанти розвитку соціальних інститутів, його впливу на соціальні та економічні процеси.

На сьогоднішній день не існує єдиної універсальної та загальновизнаної методики вимірювання соціальної напруженості. В той же час $є$ значна кількість публікацій, в яких автори обгрунтовують можливі варіанти набору показників, котрі слід включати до моделі визначення рівня соціального напруження на національному рівні. В переважній більшості випадків для вимірювання рівня соціальної напруженості проводяться анкетні опитування респондентів на основі репрезентативної вибірки. В рамках таких опитувань з'ясовується стан соціального самопочуття, рівень самоідентифікації респондентів, а також ставлення до соціальних проблем i причин, що викликають у людей занепокоєння.

На основі узагальнення наявного досвіду визначення системи емпіричних показників соціальної напруженості, в праці [10, с. 85-89] зроблено висновки про те що основними компонентами даної формалізованої системи є наступні емпіричні показники: обсяг ВРП на душу населення; індекс фізичного обсягу промислової продукції; рівень доходів на душу населення; індекс споживчих цін; реальні грошові доходи; рівень безробіття; рівень довіри до влади; низький рівень життя; соціальна незахищеність населення; житлові проблеми населення; рівень злочинності; якість та доступність вищої освіти; рівень захворюваності населення; рівень довіри до діяльності органів місцевого самоврядування; соціально-політичні орієнтації і активність населення; рівень згрунтованості регіональних еліт та їх підтримка; розвиток бізнесу; порушення прав і свобод громадян.

Т.Клебанова та О.Рудаченко [11] рекомендують використати 18 показників, динаміка значень яких відображає характер змін в соціальній, економічній та політичній сферах. До таких показників, на думку авторів слід віднести: валовий регіональний продукт, млн грн; безробітне населення (за методологією МОП); середньомісячна заробітна плата по регіонах, грн; сума заборгованості із виплати заробітної плати, млн грн; обсяг реалізованої промислової продукції за регіонами, млн грн; оборот роздрібної торгівлі, млн грн; капітальні інвестиції за регіонами, млн грн;вантажооборот, млн т-км; пасажирооборот, млн пас. км; експорт, тис. дол. США; імпорт, тис. дол. США; сальдо, тис. дол. США; кількість підприємств за їх розмірами за регіонами, шт.; заборгованість населення за послуги ЖКГ, тис. грн; загальна сума субсидій, 
призначених домогосподарствам для відшкодування витрат на оплату ЖКГ, тис. грн; кількість прибулих, осіб; кількість вибулих, осіб; міграційний приріст або скорочення.

Для оцінки рівня соціального напруження вітчизняними науковцями розроблено методики вимірювання соціального самопочуття [12] та потенціалу соціального протесту [13]. Дані методики базуються на концептуальній моделі соціальної напруженості як певного стану суспільства, що зумовлений економічною, інституціональною та ціннісною кризою, котра призводить до погіршення самопочуття різних соціальних груп, які висловлюють своє невдоволення та протест за допомогою різних політичних методів.

Для вирішення задачі кількісного оцінювання та аналізу рівня соціального напруження в регіонах України 3 урахуванням тенденцій соціального та економічного розвитку на загальнодержавному та міжнародному рівнях, в рамках проведених досліджень адаптовано 3 урахуванням наявної статистичної бази та цілей дослідження підхід до оцінювання та аналізу рівня економічної безпеки регіону, детально висвітлений в праці [14]. В рамках даного підходу пропонується застосування зваженої евклідової відстані для визначення фактичних та ретроспективних значень показника соціального напруження 3 подальшим розрахунком порогових рівнів соціального напруження та групування регіонів України за значеннями показників соціального напруження за кожен звітний період.

Для формалізованого представлення даної задачі введемо наступні позначення. Нехай $\epsilon \mathrm{m}$ регіонів, які можна дослідити за допомогою системи показників $x_{1}, x_{2}, \ldots, x_{n}$, які утворюють множину Ј. Тоді показники і-регіону можна представити об'єктами $P_{i}\left(x_{i 1}, x_{i 2}, \ldots, x_{i n}\right), j=\overline{1, m}$. Для оцінки рівня соціального напруження в $i$-регіоні оцінюємо міру близькості між об'єктами:

1. $P_{i}\left(x_{i 1}, x_{i 2}, \ldots, x_{i n}\right)$ та $P_{0}\left(x_{01}, x_{02}, \ldots, x_{0 n}\right), j=\overline{1, m}$ - ідеальним об'єктом в багатовимірному просторі, координати якого можна знайти:

$x^{*}{ }_{0 j}=\max _{i} x_{i j}^{*}$, якщо зростання $j$ - показника стимулює зниження рівня соціального напруження в регіоні, $j=\overline{1, n}$;

$x^{*}{ }_{0 j}=\min _{i} \quad x_{i j}^{*}$, якщо зростання $j$ - показника призводить до зростання рівня соціального напруження в регіоні, $j=\overline{1, n}$;

2. $P_{i}\left(x_{i l}, x_{i 2}, \ldots, x_{i n}\right)$ та $P_{c}\left(x_{c l}, x_{c 2}, \ldots, x_{c n}\right)$ - об'єктом в багатовимірному просторі, координати якого відповідають значенням системи показників на загальнонаціональному рівні;

3. $P_{i}\left(x_{i 1}, x_{i 2}, \ldots, x_{i n}\right)$ та $P_{u}\left(x_{u 1}, x_{u 2}, \ldots, x_{u n}\right)$ - об'єктом в багатовимірному просторі, координати якого відповідають значенням системи показників на міжнародному рівні.

При ненормованих осях можливою є ситуація, коли два об’єкти, котрі суттєво відрізняються тільки за одним або двома параметрами, виявляться 
далекими один від одного в евклідовому просторі. Для усунення цього недоліку проведено нормалізацію осей в евклідовому просторі. Таким чином формула знаходження відстані між двома об'єктами i та j в зваженому (нормованому) евклідовому просторі буде мати наступний вигляд:

$$
d_{i j}=\sqrt{\sum_{k=1}^{n}\left(x_{i k}^{*}-x_{j k}^{*}\right)^{2}}
$$

де ${ }^{x_{i k}^{*}=\frac{x_{i k}-\bar{x}_{k}}{\delta_{k}}}$ - нормалізоване значення $\mathrm{k}$ - ознаки в $\mathrm{i}$ - об'єкті;

$x_{j k}^{*}=\frac{x_{j k}-\bar{x}_{k}}{\delta_{k}}$ - нормалізоване значення $\mathrm{k}$ - ознаки в $\mathrm{j}$ - об'єкті;

$\bar{x}_{k}$ - середньоарифметичне значення $\mathrm{k}$ - ознаки;

$\delta_{k}$ - середньоквадратичне відхилення значення k - ознаки.

В процесі вимірювання рівня розвитку території методом зваженої евклідової відстані для врахування можливої лінійної залежності пояснювальних ознак між собою до попередньої формули введемо множник $\prod_{j^{\prime \prime}=1}^{j-1}\left(1-r_{j^{\prime \prime j}}\right)$, де ${ }^{r_{j^{\prime \prime} j}}$ - коефіцієнт кореляції Пірсона між показниками $x_{j^{\prime \prime}}^{*} i^{x_{j}^{*}} \cdot 3$ урахуванням цього функцію відстані між двома об’єктами $i$ та $j$ в зваженому (нормованому) евклідовому просторі 3 урахуванням можливої мультиколінеарності в масиві факторів можна записати наступним чином:

$$
d_{i j}=\sqrt{\sum_{k=1}^{n}\left(x_{i k}^{*}-x_{j k}^{*}\right)^{2} \prod_{k^{\prime \prime}=1}^{k-1}\left(1-r_{k^{\prime \prime} k}\right)}
$$

Враховуючи аргументи щодо вибору згортки, наведені в [14], інтегральна оцінка відстані між об'єктами в евклідовому просторі визначається за допомогою мультиплікативної згортки, тобто

$$
D_{i j}=\sqrt[p]{\prod_{s=1}^{p} d_{s i j}}
$$

Виходячи 3 таких міркувань, формули для визначення міри близькості $P_{i}\left(x_{i 1}, x_{i 2}, \ldots, x_{i n}\right)$ та $P_{0}\left(x_{01}, x_{02}, \ldots, x_{0 n}\right)$ будуть мати вигляд:

для часткових оцінок:

$$
d_{s i 0}=\sqrt{\sum_{k=1}^{n_{s}}\left(x_{s i k}^{*}-x_{s o k}^{*}\right) \prod_{k^{\prime}=1}^{k-1}\left(1-r_{k^{\prime \prime} k}\right)},
$$

для інтегральної оцінки:

$$
D_{i 0}=\sqrt[p]{\prod_{s=1}^{p} d_{s i 0}},
$$

де $x_{s i k}^{*}$ - стандартизоване значення $k$ - показника $s$ - підсистеми $i$ - об'єкта; $x^{*}{ }_{s o k}$ - стандартизоване значення $k$ - показника $s$ - підсистеми ідеального об'єкта; 
$n_{s}$ - кількість показників в $s$ - підсистемі;

$r_{k k}^{\prime}$ - коефіцієнт кореляції Пірсона між показниками $x_{s i k}^{*}$ та $x_{s o k}^{*}$;

$p$ - кількість підсистем;

$d_{s i o}$ - оцінка відстані між $s$ - підсистемою показників $i$ - об’єкта та ідеального об'єкта;

$D_{i 0}$ - інтегральна оцінка відстані між об'єктами $P_{i}$ та $P_{0 .}$

Аналогічно запишемо формули для визначення міри близькості об'єктів $P_{i}\left(x_{i 1}, x_{i 2}, \ldots, x_{i n}\right)$ та $P_{c}\left(x_{c 1}, x_{c 2}, \ldots, x_{c n}\right)$ :

$$
\begin{gathered}
d_{s i c}=\sqrt{\sum_{k=1}^{n_{s}}\left(x_{s i k}^{*}-x_{s c k}^{*}\right) \prod_{k^{\prime}=1}^{2}\left(1-r_{k^{\prime \prime} k}\right)}, D_{i c}=\sqrt[p]{\prod_{s=1}^{p} d_{s i c}} \\
P_{i}\left(x_{i 1}, x_{i 2}, \ldots, x_{i n}\right) \text { та } P_{u}\left(x_{u 1}, x_{u 2}, \ldots, x_{u n}\right): \\
d_{s i u}=\sqrt{\sum_{k=1}^{n_{s}}\left(x_{s i k}^{*}-x_{s u k}^{*}\right)^{2} \prod_{k^{\prime}=1}^{k-1}\left(1-r_{k^{\prime \prime} k}\right)} ; \quad D_{i u}=\sqrt[p]{\prod_{s=1}^{p} d_{s i u}} .
\end{gathered}
$$

В такому випадку справедливими будуть твердження:

1. Чим меншим $є$ значення $D_{i 0}$, тим нижчим $\epsilon$ рівень соціального напруження в $i$ - му регіоні і навпаки;

2. Чим меншим є значення $D_{i c}$, та $D_{i u}$, тим ближчим за рівнем соціального напруження $є$ - й регіон відповідно до середнього по Україні та міжнародного рівнів і навпаки;

3. У випадку $D_{i u}>D_{i c}$ - за рівнем соціального напруження $i$ - й регіон відстає від середньоукраїнського рівня;

4. У випадку $D_{i 0}>D_{i u}, D_{i 0}>D_{i c}$ - на території за досліджуваний період відбувалося зростання рівня соціального напруження вищими темпами порівняно із середньоукраїнськими та світовими тенденціями.

Проведений за такою методикою аналіз дозволив отримати інформацію про динаміку рівня соціальної напруженості і регіонах України за період 3 1996 по 2020 рік.

Висновки. 3 урахуванням результатів проведеного аналізу вітчизняних та зарубіжних методик оцінювання, аналізу та прогнозування соціальної напруженості можна стверджувати, що актуальними і затребуваними будуть розробки комплексних методик, котрі поєднуватимуть в собі переваги як підходів до оцінювання соціальної напруженості на основі опитування респондентів, так і методик, заснованих на використанні статистичних та математичних методів аналізу статистичної інформації. Для вирішення задачі оцінювання та аналізу рівня соціального напруження регіонів України 3 урахуванням процесів, котрі відбуваються на загальнодержавному та міжнародному рівнях запропоновано використання зваженої евклідової відстані. Подальший розвиток обраного напряму досліджень дозволить розробити комплексну методику оцінювання, аналізу та прогнозування рівня соціального напруження в регіональному розрізі, котра може стати основою 
для здійснення моніторингу та управління процесами забезпечення соціальної та економічної безпеки держави та її регіонів.

\section{Лimepamypa:}

1. Судаков B.I. Соціальна напруженість як теоретична та емпірична проблема соціологічного аналізу / Проблеми розвитку соціологічної теорії: матеріали XIV Міжнар. наук.-практ. конф. «Проблеми розвитку соціологічної теорії: Структурні зміни і соціальна напруженість», 25-26 трав. 2017 р., (м. Київ)/ Наукове видання/ Київ. нац., ун-т ім..Т.Шевченка [під заг ред. Горбачика А.П., Судакова В.І.]. - К.:Логос, 2017. - 197 с. с. 6-9.

2. Рудаченко О.О. Сучасні підходи до аналізу соціальної напруженості / О.О. Рудаченко, Т.С. Клебанова // Науковий вісник Ужгородського національного університету. -2020. - Випуск 30. - с. 140-144.

3. Паніотто В. Чинники щастя і соціальна напруженість / Проблеми розвитку соціологічної теорії: матеріали XIV Міжнар. наук.-практ. конф. «Проблеми розвитку соціологічної теорії: Структурні зміни і соціальна напруженість», 25-26 трав. 2017 р., (м. Київ)/ Наукове видання/ Київ. нац., ун-т ім..Т.Шевченка [та ін.; під заг ред. Горбачика А.П., Судакова В.I.]. - К.:Логос, 2017. - 197 с. с. 10-11.

4. Клебанова Т.С. Побудова інтегральних показників напруженості соціальноекономічного розвитку країни / Т.С. Клебанова., О.О. Рудаченко, О.В. Панасенко // Приазовський економічний вісник. - 2021. - Випуск 2 (25). - с. 19-23.

5. Клебанова Т.С., Рудаченко О.О. Моделювання критичних факторів соціальної напруженості в Україні шляхом множинного регресійного аналізу / Т.С. Клебанова, O.O. Рудаченко // Науковий погляд: економіка та управління. - 2019.- № 2 (64). - с. 102-110.

6. Соціальна напруженість у кризовому соціумі: соціальнопсихологічний аналіз / [О.Г. Злобіна, М.О. Шульга, Л.Д. Бевзенко та ін.]; за наук. ред. О.Г. Злобіної. - Київ : Ін-т соціології НАН України, 2019. - 291 с.

7. Сірий Є.В. Теоретичні та методологічні засади системного аналізу та побудови концептуальної моделі соціальної напруженості / Є.В. Сірий // Вісник ОНУ ім. I.I. Мечникова. - 2016. - Т.21. Вип. 3 (26). - с. 49-58.

8. Баранова Г.В. Социальная напряженность: особенности методологии и методики ее анализа и прогнозирования в регионах Российской Федерации. Автореферат диссертации на соискание ученой степени кандидата социологических наук. М. 2009., 28c.

9. Едвардс Л. Естественная история революции / Л. Едвардс // Социологический журнал. 2005. №1. с. 101-131. - Режим доступу: https://www.jour.fnisc.ru/upload/journals/1/ articles/856/submission/original/856-1575-1-SM.pdf.

10. Лапіна В.В. Теоретичні аспекти проблеми ідентифікації соціальних чинників та емпіричних показників соціальної напруженості в Україні та іiі регіонах/ Проблеми розвитку соціологічної теорії: матеріали XIV Міжнар. наук.-практ. конф. «Проблеми розвитку соціологічної теорії: Структурні зміни і соціальна напруженість», 25-26 трав. 2017 р., (м. Київ)/ Наукове видання/ Київ. нац., ун-т ім..Т.Шевченка [та ін.; під заг ред. Горбачика А.П., Судакова В.І.]. - К.:Логос, 2017. - 197 с. с. 85-89.

11. Рудаченко О.О. Класифікація регіонів України за рівнем формування соціальної напруженості / О.О. Рудаченко, Т.С. Клебанова // Бізнес Інформ. - 2020. - №10. - с. 128-136.

12. Головаха Е.И., Потенциал протеста украинского общества / Е.И. Головаха, Н.В. Панина // Социологические исследования. - 1999. - №. 10. - с. 31-40.

13. Головаха Е.И. Измерение социального самочувствия: тест ИИСС / Е.И. Головаха, Н.В. Панина, А.П. Горбачик // Социология: методология, методы, математическое моделирование. - 1998. - №. 10. - с. 45-71.

14. Пілько А. Д. Моделювання процесів управління економічною безпекою регіону : дис. ... канд. екон. наук : 08.03.02 / Пілько Андрій Дмитрович. - Івано-Франківськ, 2004. 203 с. 


\section{References:}

1. Sudakov V.I. (2017) Sotsialna napruzhenist yak teoretychna ta empirychna problema sotsiolohichnoho analizu [Social stress is theoretical and empirical problem of sociological analysis]. Proceedings from Mizhnar. nauk.-prakt. konf. «Problemy rozvytku sotsiolohichnoyi teoriyi: Strukturni zminy $i$ sotsialna napruzhenist» - International Scientific and Practical Conference Problems of development of sociological theory: materials XIV. "Problems of development of sociological theory: Structural changes and social tension" (pp. 6-9). Kyiv: «Lohos», 2017» [in Ukrainian].

2. Rudachenko O.O., \& Klebanova T.S. (2020). Suchasni pidkhody do analizu sotsialnoyi napruzhenosti [Modern approaches to the analysis of social tension]. Naukovyy visnyk Uzhhorodskoho natsionalnoho universytetu - Scientific Bulletin of Uzhhorod National University 30, 140-144 [in Ukrainian].

3. Paniotto V. (2017) Chynnyky shchastya i sotsialna napruzhenist [Factors of happiness and social tension] Proceedings from Mizhnar. nauk.-prakt. konf. "Problemy rozvytku sotsiolohichnoyi teoriyi: Strukturni zminy i sotsialna napruzhenist» - International Scientific and Practical Conference Problems of development of sociological theory: materials XIV. "Problems of development of sociological theory: Structural changes and social tension" (pp. 10-11). Kyiv: «Lohos», 2017» [in Ukrainian].

4. Klebanova T.S., \& Rudachenko O.O., \& Panasenko O.V. (2021). Pobudova intehralnykh pokaznykiv napruzhenosti sotsialno-ekonomichnoho rozvytku krayiny [Construction of integrated indicators of the intensity of socio-economic development of the country]. Pryazovs'kyy ekonomichnyy visnyk - Priazovsky Economic Bulletin 2 (25), 19-23 [in Ukrainian].

5. Klebanova T.S., \& Rudachenko O.O. (2019). Modelyuvannya krytychnykh faktoriv sotsialnoyi napruzhenosti $\mathrm{v}$ Ukrayini shlyakhom mnozhynnoho rehresiynoho analizu [Modeling of critical factors of social tension in Ukraine by multiple regression analysis]. Naukovyy pohlyad: ekonomika ta upravlinnya - Scientific view: economics and management 2 (64), 102-110 [in Ukrainian].

6. Zlobina, O.H., Shulha, M.O., \& Bevzenko, L.D. (2019) Sotsialna napruzhenist u kryzovomu sotsiumi: sotsialnopsykholohichnyy analiz [Social tension in a crisis society: sociopsychological analysis]. - Kyiv : In-t sotsiolohiyi NAN Ukrayiny. [in Ukrainian].

7. Siryy Ye.V. (2016) Teoretychni ta metodolohichni zasady systemnoho analizu ta pobudovy kontseptualnoyi modeli sotsialnoyi napruzhenosti [Theoretical and methodological principles of systems analysis and construction of a conceptual model of social tension]. Visnyk ONU im. I.I. Mechnykova Bulletin of ONU named after I.I. Mechnikov, 3 (26), 49-58 [in Ukrainian].

8. Baranova G.V (2009). Sotsialnaya napryazhennost: osobennosti metodologii i metodiki yeye analiza i prognozirovaniya $\mathrm{v}$ regionakh Rossiyskoy Federatsii [Social tension: features of methodology and methods of its analysis and forecasting in the regions of the Russian Federation ]. Extended abstract of candidate's thesis. Moscow [in Russian].

9. Yedvards L. (2005). Yestestvennaya istoriya revolyutsii [The natural history of the revolution ]. Sotsiologicheskiy zhurnal - Sociological Journal, 1, 101-131. Retrieved from https://www.jour.fnisc.ru/ upload/journals/1/articles/856/submission/original/856-1575-1-SM.pdf [in Russian].

10. Lapina V.V. (2017) Teoretychni aspekty problemy identyfikatsiyi sotsial'nykh chynnykiv ta empirychnykh pokaznykiv sotsialnoyi napruzhenosti v Ukrayini ta yiyi rehionakh [Theoretical aspects of the problem of identification of social factors and empirical indicators of social tension in Ukraine and its regions] Proceedings from Mizhnar. nauk.-prakt. konf. «Problemy rozvytku sotsiolohichnoyi teoriyi: Strukturni zminy i sotsialna napruzhenist» - International Scientific and Practical Conference Problems of development of sociological theory: materials XIV. "Problems of development of sociological theory: Structural changes and social tension" (pp. 85-89). Kyiv: «Lohos», 2017» [in Ukrainian]. 
11. Rudachenko O.O., \& Klebanova T.S. (2020) Klasyfikatsiya rehioniv Ukrayiny za rivnem formuvannya sotsialnoyi napruzhenosti [Classification of regions of Ukraine according to the level of formation of social tension] Biznes Inform - Business Inform, 10, 128-136 [in Ukrainian].

12. Golovakha Ye.I., \& Panina N.V. (1999) Potentsial protesta ukrainskogo obshchestva [The potential for protest in Ukrainian society] Sotsiologicheskiye issledovaniya - Sociological research, 10, 31-40 [in Russian].

13. Golovakha Ye.I., \& Panina N.V., \& Gorbachik A.P. (1998) Izmereniye sotsial'nogo samochuvstviya: test IISS [Measuring social well-being: the ISSS test] Sotsiologiya: metodologiya, metody, matematicheskoye modelirovaniye - Sociology: methodology, methods, mathematical modeling, 10, 45-71 [in Russian].

14. Pilko A.D. (2004) Modelyuvannya protsesiv upravlinnya ekonomichnoyu bezpekoyu rehionu [Modeling of economic security management processes in the region]. Candidate's thesis. Ivano-Frankivsk [in Ukrainian]. 